\title{
Experimental Design as a Tool for Optimization of C-Phycocyanin Purification by Precipitation from Spirulina platensis
}

\author{
Lorena A. Silva, Kátia R. Kuhn, Caroline C. Moraes, Carlos A. V. Burkertand Susana J. Kalil* \\ Departamento de Química, Fundação Universidade Federal do Rio Grande, \\ CP 474, 96201-900 Rio Grande-RS, Brazil
}

\begin{abstract}
C-ficocianina é um pigmento natural azul que pode ser utilizado como aditivo alimentar e na indústria farmacêutica. Esse trabalho visou obter C-ficocianina com aumento na pureza e sem perdas na recuperação, empregando a técnica da precipitação. O extrato bruto de C-ficocianina foi utilizado nos ensaios. A otimização da purificação foi feita através de um planejamento experimental, no qual avaliou-se a concentração de sulfato de amônio, o volume e o pH de tampão de re-suspensão. Subseqüentemente, um estudo da purificação utilizando o fracionamento com sulfato de amônio foi realizado nas melhores condições encontradas no planejamento experimental. As condições mais favoráveis para a purificação foram obtidas quando foi utilizado fracionamento com sulfato de amônio na faixa 0-20\%/20-50\%, relação volume de re-suspensão/volume inicial de 0,52 e tampão $\mathrm{pH}$ 7,0. Nessas condições, em um único passo de purificação, a pureza aumentou 70\% comparado ao extrato inicial e a recuperação foi de $83,8 \%$.
\end{abstract}

C-phycocyanin is a natural blue dye that has been used as an additive in food and can be used to produce medications. The major goal of the present study was to obtain C-phycocyanin under the best operational conditions for high C-phycocyanin recovery and purity using the precipitation technique. Crude C-phycocyanin from Spirulina platensis was used. Optimization of the purification was carried out using experimental design. The effect of ammonium sulfate concentration, volume and of $\mathrm{pH}$ for resuspension were evaluated. Subsequently an ammonium sulfate fractionation study was carried out using the most suitable conditions found in the experimental design. The best purification condition was ammonium sulfate fractionation at $0-20 \% / 20-50 \%$, in relation to a resuspension volume/initial volume of 0.52 in a $7.0 \mathrm{pH}$ buffer. Under these conditions, in an one-step purification only, the purity increased $70 \%$ compared to the initial extract, with an $83.8 \%$ recovery.

Keywords: precipitation, ammonium sulfate, experimental design, C-phycocyanin

\section{Introduction}

Phycobiliproteins are proteins with linear tetrapyrrole prosthetic groups (bilins) that, in their functional state, are covalently linked to specific cysteine residues of proteins. ${ }^{1}$ Phycobiliproteins are derived from cyanobacteria and red algae. They are water-soluble and highly fluorescent, and can constitute up to $60 \%$ of the soluble protein content. ${ }^{2}$ These proteins are attractive since they are not harmful to human beings if applied to external surfaces or ingested. The three main classes of phycobiliproteins are: phycoerythrin (PE, $\lambda_{\text {max }} 540-570 \mathrm{~nm}$ ), phycocyanin (PC, $\lambda_{\text {max }} 610-620 \mathrm{~nm}$ ) and allophycocyanin (APC, $\lambda_{\text {max }} 650-655 \mathrm{~nm}$ ). These classes differ significantly in their protein structure and pigment

\footnotetext{
*e-mail: susana.kalil@vetorial.net
}

content. ${ }^{3,4}$ Visually, phycoerythrins are red, phycocyanins range from purple (phycoerythrocyanin, R-phycocyanin) to deep blue (C-phycocyanin), and allophycocyanins are blue with a hint of green. ${ }^{1,2}$

The phycocyanins are blue and have many commercial applications in food and cosmetics. ${ }^{5}$ Recent studies have demonstrated hepatoprotective, ${ }^{6}$ anti-inflammatory ${ }^{6-8}$ and antioxidant ${ }^{9,10}$ properties of PC. Due to their limited distribution, these pigments are rather expensive, and obtaining them as pure compounds is a potentially attractive endeavor. $^{11}$

As the culture of algae and cyanobacteria is eco-friendly and renewable, there is an increasing tendency to use them as a source of natural colors. Many authors have reported the production of C-PC from Spirulina platensis. It is feasible to culture this cyanobacteria on a large scale using 
Mangueira Lagoon water (situated in the extreme South of Brazil between the Atlantic Ocean and the Mirim Lagoon in Rio Grande do Sul State) supplemented with urea. This culture medium is able to reduce production costs and improve the economics of its large-scale cultivation. ${ }^{12}$

The purity of C-PC is generally evaluated using the absorbance ratio of $\mathrm{A}_{620} / \mathrm{A}_{280}$, and a purity of 0.7 is considered as food grade, 3.9 as reactive grade and greater than 4.0 as analytical grade. ${ }^{13,14}$ Purity is directly related to process costs, and in general, the more purified a product is, the more expensive to obtain it. Wheelwright ${ }^{15}$ pointed out that the downstream recovery represented a large part of the production costs and in some cases it may be the major manufacturing cost.

If the intention is to obtain a natural dye for food use, there is no need for a great number of purification steps. Instead one should invest in the parameter optimization of each step of the process, aiming to obtain a product with the necessary purity grade. Protein purification techniques use, such as, ammonium sulfate precipitation is of great value, since it can be applied on a large-scale and requires simple equipment and is simple and cheap to carry out. ${ }^{11}$ Moreover, for recovering C-phycocyanin biological activity, it is usually excellent after precipitation and its dissolution is easy. There is no standard procedure to purify C-phycocyanin using ammonium sulfate precipitation, therefore it is interesting to study and establish this procedure to reach the maximum possible purity.

Proteins precipitation occurs due to salting out effect, as a result of the competition between protein and saline ions for water molecules, leading to hydration water removal from protein. A greater protein-protein interaction happens, which becomes stronger than protein-water interaction, resulting in aggregation of protein molecule followed by their precipitation. ${ }^{16}$ However many proteins precipitate in a narrow salt concentration range, making this method efficient for fractionation. ${ }^{17}$

However, despite the fact that many authors have used ammonium sulfate precipitation as a step in the biliprotein purification process, ${ }^{18-20}$ or in enzyme purification, ${ }^{21-23}$ no reports were found on the optimization of this step using experimental designs, nor studies on the process parameters and their influence. Considering the process costs, it is extremely advantageous to obtain the maximum yield and purity of the bioproduct in each step. Hence, optimization could supply a bioproduct with the required purity grade with less purification steps. There are some methods to optimize a chemical process, with advantages and disadvantages, as reported by Ferreira et al. ${ }^{24,25}$ However, the most popular method to optimize a step is the central composite design, due to simplicity and relatively low cost.
Taking into account the multiple uses of C-PC and the inexistence of a standard procedure to purify it by ammonium sulfate precipitation, this paper presents the optimization of the precipitation of C-phycocyanin from Spirulina platensis, using an experimental design to obtain food grade dye with only one step of purification, for food industry use.

\section{Experimental}

\section{Culture conditions and C-phycocyanin extraction}

Spirulina platensis strain LEB-52 26 was grown and maintained in an open outdoor photo-bioreactor, under uncontrolled conditions, in South Brazil. During this cultivation, water was supplemented with $20 \%$ Zarrouk synthetic medium. ${ }^{27}$ This medium was also used to prepare the biomass for the initial inoculation of each batch. All reagents used were of analytical grade, obtained from Merck (Darmstadt, Germany) and Synth (São Paulo, Brazil).

The initial biomass concentration was $0.15 \mathrm{~g} \mathrm{~L}^{-1}$ and at the end of cultivation ( 30 days), the biomass was recovered by filtration, dried at $40{ }^{\circ} \mathrm{C}$ for $48 \mathrm{~h}$, frozen at $-18{ }^{\circ} \mathrm{C}$, homogenized and sieved (150 mesh).

C-PC extraction was carried out according to Silveira et al. ${ }^{28}$ who used water as solvent in a rotary shaker and whose product was defined as crude extract.

\section{C-Phycocyanin stability}

The stability of the phycocyanin was studied in a $\mathrm{pH}$ range from 3.0 to 10.5 using different buffers at 10 and $25^{\circ} \mathrm{C}$ for 5 days. The buffers used were: citrate phosphate buffer in the range from $\mathrm{pH} 3.0$ to $\mathrm{pH} 5.0$, sodium phosfate buffer $\mathrm{pH} 6.0$ to $\mathrm{pH} 8.0$, Tris- $\mathrm{HCl}$ buffer $\mathrm{pH} 9.5$, glycine buffer $\mathrm{pH} 10.5$.

\section{C-Phycocyanin purification}

C-PC crude extract was used for purification. For experiments comparison, the same crude extract was used to obtain the same initial conditions.

\section{C-phycocyanin precipitation optimization by experimental} design

C-PC extracted from Spirulina platensis was precipitated with solid ammonium sulfate. Salt was added and the solution allowed to stand overnight and then centrifuged at $1800 \mathrm{~g}$ for $30 \mathrm{~min}$ at room temperature. The blue precipitate 
Table 1. Values of the uncoded levels used in the experimental design

\begin{tabular}{lccc}
\hline Coded variable level & $\begin{array}{c}\text { Ammonium sulfate concentration / } \\
(\%, \mathrm{~m} / \mathrm{v})\end{array}$ & $\begin{array}{c}\text { Resuspension volume/ } \\
\text { initial volume ratio }\end{array}$ & $\begin{array}{c}\mathrm{pH} \text { of buffer used } \\
\text { in resuspension }\end{array}$ \\
\hline-1.68 & 43.2 & 0.18 & 5.6 \\
-1 & 50 & 0.25 & 5.9 \\
0 & 60 & 0.35 & 6.3 \\
+1 & 70 & 0.45 & 6.7 \\
+1.68 & 76.8 & 0.52 & 7.0 \\
\hline
\end{tabular}

was re-suspended in phosphate buffer, using a resuspension volume/initial volume ratio $(\mathrm{Vr} / \mathrm{Vi})$ according to the experimental design. All parameters were studied using a $2^{3}$ experimental design with 3 central points and 6 axial points, giving a total of 17 trials. ${ }^{29}$ Five levels were chosen for each independent variable, with upper and lower limits set in the range as described in the literature. Table 1 shows the values of the uncoded levels used in the experimental design and Table 3, the matrix and the responses for these experiments.

\section{C-Phycocyanin precipitation by ammonium sulfate fractionation}

Crude extracts of C-PC were fractionated with solid $\left(\mathrm{NH}_{4}\right)_{2} \mathrm{SO}_{4}$ at room temperature according to Table 2. The fraction obtained with $50 \%$ of ammonium sulfate was rich in C-phycocyanin, which was dissolved using a $\mathrm{Vr} / \mathrm{Vi}$ of 0.52 in $50 \mathrm{mmol} \mathrm{L}^{-1}$ phosphate buffer $\mathrm{pH} 7.0$, according to the values established in the experimental design. All the trials were carried out in triplicate.

Table 2. Variations in the saturation range used during the ammonium sulfate fractionation up to $50 \%$

\begin{tabular}{lc}
\hline Trial & Fractionation / $(\mathrm{m} / \mathrm{v})$ \\
\hline 1 & $0-20 \% / 20-50 \%$ \\
2 & $0-25 \% / 25-50 \%$ \\
3 & $0-35 \% / 35-50 \%$ \\
4 & $0-40 \% / 40-50 \%$ \\
\hline
\end{tabular}

\section{Purification by fractionation versus direct precipitation}

In order to compare ammonium sulfate fractionation results with those of direct precipitation at $50 \%$ saturation, a new extraction was carried out. In these trials, the best result was used for both the fractionation and the experimental design, which was called direct precipitation. All trials were carried out in triplicate.
Table 3. Coded levels for a full factorial design, C-phycocyanin concentration (C-PC), extract purity (EP) and recovery (REC) during purification

\begin{tabular}{lcccccc}
\hline Trial & $\mathrm{X}_{1}$ & $\mathrm{X}_{2}$ & $\mathrm{X}_{3}$ & $\mathrm{REC} /(\%)$ & $\mathrm{EP}$ & $\begin{array}{c}\mathrm{C}-\mathrm{PC} / \\
\left(\mathrm{mg} \mathrm{mL}^{-1}\right)\end{array}$ \\
\hline 1 & -1 & -1 & -1 & 71.7 & 0.89 & 4.6 \\
2 & 1 & -1 & -1 & 66.3 & 0.72 & 4.1 \\
3 & -1 & 1 & -1 & 76.3 & 0.73 & 3.3 \\
4 & 1 & 1 & -1 & 75.4 & 0.64 & 3.1 \\
5 & -1 & -1 & 1 & 69.4 & 0.79 & 5.0 \\
6 & 1 & -1 & 1 & 69.6 & 0.67 & 3.6 \\
7 & -1 & 1 & 1 & 82.4 & 0.82 & 3.9 \\
8 & 1 & 1 & 1 & 79.8 & 0.75 & 3.5 \\
9 & 0 & 0 & 0 & 60.9 & 0.57 & 3.7 \\
10 & 0 & 0 & 0 & 62.7 & 0.62 & 3.8 \\
11 & 0 & 0 & 0 & 62.0 & 0.59 & 3.0 \\
12 & -1.68 & 0 & 0 & 4.7 & 0.64 & 0.5 \\
13 & 1.68 & 0 & 0 & 49.7 & 0.64 & 2.4 \\
14 & 0 & -1.68 & 0 & 44.3 & 0.82 & 4.3 \\
15 & 0 & 1.68 & 0 & 55.4 & 0.76 & 2.4 \\
16 & 0 & 0 & -1.68 & 54.4 & 0.75 & 2.9 \\
17 & 0 & 0 & 1.68 & 52.7 & 0.79 & 3.3 \\
\hline $\mathrm{X}$ & & & & & &
\end{tabular}

$\mathrm{X}_{1}=$ Ammonium sulfate concentration $(\%, \mathrm{~m} / \mathrm{v}), \mathrm{X}_{2}=$ Resuspension volume/initial volume ratio, $\mathrm{X}_{3}=\mathrm{pH}$.

\section{Analytical procedures}

\section{Extract purity}

C-phycocyanin extract purity (EP) was monitored from the $\mathrm{A}_{620} / \mathrm{A}_{280}$ ratio. ${ }^{30}$ Absorbance at $620 \mathrm{~nm}$ indicates the maximum C-PC absorption, while at $280 \mathrm{~nm}$, it is due to the concentration of proteins in solution. ${ }^{19}$

\section{C-Phycocyanin concentration}

C-phycocyanin concentration was calculated in $\mathrm{mg} \mathrm{mL}^{-1}$ by absorbance at 652 and $620 \mathrm{~nm}$, using the Bennet and Bogorad formula: ${ }^{4}$

$\mathrm{C}-\mathrm{PC}=\frac{\left(\mathrm{A}_{620}-0.474\left(\mathrm{~A}_{652}\right)\right)}{5.34}$ 


\section{C-Phycocyanin recovery}

C-phycocyanin recovery (REC) was calculated using the following formula:

$\mathrm{REC}=\frac{\mathrm{C}-\mathrm{PC} \times \text { Resuspension volume }}{\mathrm{C}-\mathrm{PC} \text { extract initial } \times \text { initial volume }} \times 100$

\section{Purification factor}

The purification factor was given by the relationship between the extract purity after and before the precipitation step, respectively.

\section{Statistics}

Statistica 6.0 software was used for statistical analysis and for graphs. Response surfaces and contour diagrams were drawn according to Rodrigues and Iemma ${ }^{31}$ and Kalil et al. ${ }^{32}$ Statistical differences were assessed by Tukey's test and mean differences between groups were compared by a one-way analysis of variance (ANOVA) and were expressed as the mean $\pm \mathrm{SD}$. The difference was considered to be statistically significant when $\mathrm{p}<0.05$.

\section{Results and Discussion}

\section{C- Phycocyanin stability}

A 5-day stability study indicated that C-phycocyanin was stable from 5.0 to $7.0 \mathrm{pH}$ at 10 and $25^{\circ} \mathrm{C}$ (Figure $1 \mathrm{~A}$ and Figure 1B). This result agrees with that of Sarada et al., ${ }^{33}$ who reported stability from 5.0 to $7.5 \mathrm{pH}$ for C-phycocyanin from Spirulina sp. Thus, purification should be carried out in this $\mathrm{pH}$ range, in which $\mathrm{C}$-phycocyanin is more stable.

Data showed that for $\mathrm{pH}$ values below 5.0 and above 7.0, the dye has already lost color on the first day, maintaining its concentration during the next few days, except at $\mathrm{pH}$ 8.0, in which color was gradually changing. C-Phycocyanin shown to be unstable at extreme $\mathrm{pH}$ values, once at $\mathrm{pH} 3.0$, concentration was approximately $2 \%$ of the concentration before changing $\mathrm{pH}$. It must be pointed out that samples at 3.0, 9.5 and $10.5 \mathrm{pH}$ showed a green color.

Phycocyanin color is associated with the maintenance of the protein structure, ${ }^{34}$ thus at extreme $\mathrm{pH}$ values its structure is denatured even under refrigeration. However, some studies have reported that the stability of $\mathrm{C}$-phycocyanin can be increased by using stabilizers such as some polyols like sorbitol, ${ }^{35}$ making it possible to use $\mathrm{C}$-phycocyanin in acid foods and in foods that require pasteurization, without lossing its chemical properties.

\section{C-phycocyanin precipitation optimization by experimental design}

Experimental conditions and results for C-phycocyanin concentration (C-PC), extract purity (EP) and recovery (REC), for this experimental design are shown in Table 3. Recovery ranged from 4 to $80 \%$ according to experimental conditions, concentration between 0.5 and $5.0 \mathrm{mg} \mathrm{mL}^{-1}$ and extract purity from 0.57 to 0.89 .

A second order model could predict the extract purity (dependent variable) as a function of the ammonium sulfate concentration, the relation of resuspension volume, initial volume and $\mathrm{pH}$ (independent variables). Variance analysis (ANOVA) was used to evaluate fit adequacy. Based on ANOVA, as shown in Table 4, for extract purity,

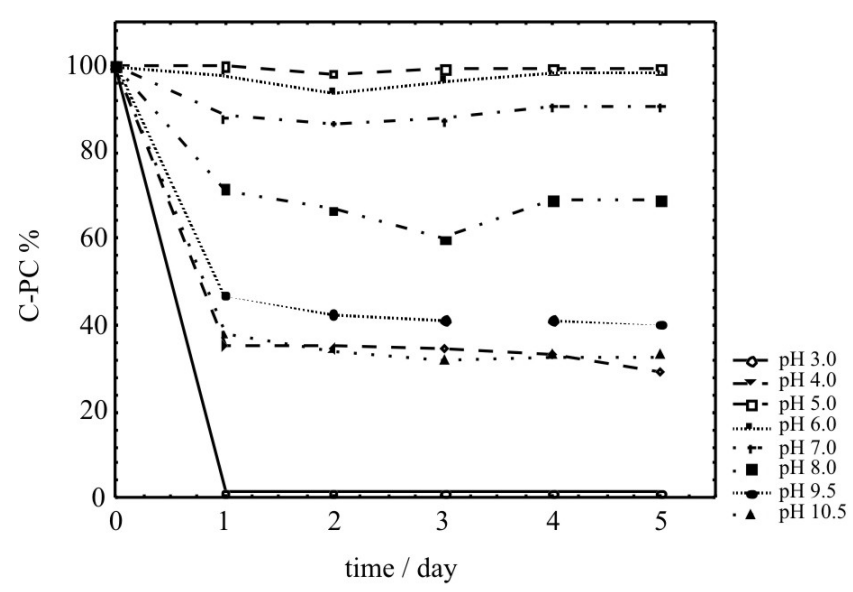

A

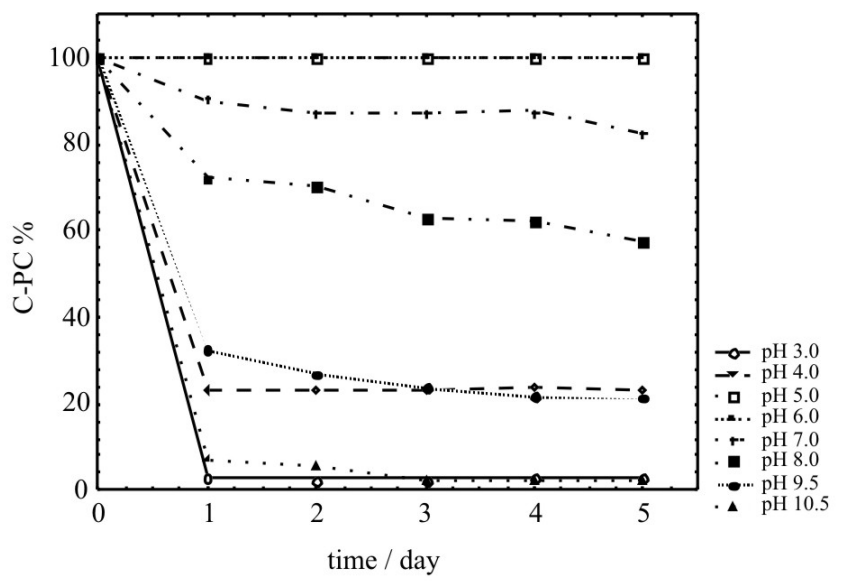

B

Figure 1. Stability of phycocyanin at different $\mathrm{pH}$ values: A, Stability of C-phycocyanin at $10{ }^{\circ} \mathrm{C}$; and B, Stability of C-phycocyanin at $25^{\circ} \mathrm{C}$. 
Table 4. ANOVA for extract purity

\begin{tabular}{lcccc}
\hline $\begin{array}{l}\text { Source of } \\
\text { variation }\end{array}$ & $\begin{array}{c}\text { Sum of } \\
\text { Squares }\end{array}$ & $\begin{array}{c}\text { Degrees of } \\
\text { freedom }\end{array}$ & $\begin{array}{c}\text { Mean } \\
\text { Squares }\end{array}$ & $F$ test \\
\hline Regression & 0.110 & 4 & 0.027 & 13.5 \\
Residual & 0.023 & 12 & 0.002 & \\
Lack of fit & 0.022 & 10 & 0.002 & 3.33 \\
Pure error & 0.001 & 2 & 0.0006 & \\
\hline Total & 0.133 & 16 & 0.008 & \\
\hline Coefficient of determination: $0.83, F_{0.95 ; 4 ; 12}=3.26$. & &
\end{tabular}

a second order model was established. The coefficient of determination was 0.83 and the $\mathrm{F}$ value about four times higher than the listed value for $95 \%$ confidence. Effects, which were not statistically significant, were ignored. The following equation was obtained:

$$
\begin{aligned}
\mathrm{EP}=0.616-0.033\left(\mathrm{X}_{1}\right)+0.066\left(\mathrm{X}_{2}\right)^{2} & \\
+ & 0.059\left(\mathrm{X}_{3}\right)^{2}+0.044\left(\mathrm{X}_{2}\right)\left(\mathrm{X}_{3}\right)
\end{aligned}
$$

where $\mathrm{EP}$ is the extract purity, $\mathrm{X}_{1}$ is the ammonium sulfate concentration, $\mathrm{X}_{2}$ is the resuspension volume/initial volume ratio and $\mathrm{X}_{3}$ is the buffer $\mathrm{pH}$ used in the resuspension.

Using the above equation, it was possible to obtain the response surfaces for extract purity (Figure 2).

Using response surface analysis, according to Figure $2 \mathrm{~A}$ and Figure 2B, it was observed that the highest extract purity was obtained using an ammonium sulfate concentration of $43.2 \%$ and $50 \%$ of saturation and a high or low $\mathrm{Vr} / \mathrm{Vi}$. However it was preferable to work at a high $\mathrm{Vr} / \mathrm{Vi}$, considering the higher recovery, as observed in Table 1, in trials 7 and 14 .

Figures $2 \mathrm{C}$ and 2D show that in order to get an extract purity of about 1.0, a resuspension volume/initial volume ratio of 0.52 and $\mathrm{pH} 7.0$ buffer in resuspension should be used. Although values of about 1.1 were obtained for extract purity using a low $\mathrm{Vr} / \mathrm{Vi}$ ratio and $\mathrm{pH} 5.6$ buffer in resuspension, these conditions were not chosen for the reasons previously described in reference to Figures $2 \mathrm{~A}$ and 2B. These conclusions become even clearer when Figures $2 \mathrm{E}$ and $2 \mathrm{~F}$ are observed, since it can be seen that the highest $\mathrm{C}$-phycocyanin purity was obtained with $\mathrm{pH}$ 7.0 and $\left(\mathrm{NH}_{4}\right)_{2} \mathrm{SO}_{4}$ concentration of $50 \%$.

From the response surfaces analysis, the best working conditions for the highest extract purity, without recovery losses were: an ammonium sulfate concentration of about $50 \%$ of saturation, a high resuspension volume/initial volume (0.52) ratio and a $7.0 \mathrm{pH}$ buffer in resuspension.

After establishing the best conditions using the experimental design, three experiments were carried out, obtaining a mean extract purity of 0.89 , C-PC concentration of $2.33 \mathrm{mg} \mathrm{mL}^{-1}$ and $91.2 \%$ recovery. Values for extract purity and C-phycocyanin concentration in the original crude extract were 0.52 and $1.99 \mathrm{mg} \mathrm{mL}^{-1}$, respectively.

Many other authors have used precipitation with ammonium sulfate as part of the C-phycocyanin purification process. However, it must be pointed out that the phycocyanin source is important, because each biomass shows a different behavior with respect to the different purification processes, and it is not possible to compare results from different biomasses.

In contrast with C-PC purification from S. platensis precipitation by Bhaskar et al. ${ }^{36}$ and by Boussiba and Richmond $^{37}$, with a purity increase of 1.4 times, in our work, the obtained increase was 1.7 times, almost without recovery losses. This was due to the use of an experimental design and analysis of the response surfaces, which allowed for the process optimization to maximize the responses. A simple and efficient purification procedure can significantly reduce the overall costs and can affect process viability. The optimization step is very important to reach the best results for purity, without significant losses in recovery, since C-phycocyanin is a product with a high aggregated value. ${ }^{38}$

\section{C-phycocyanin precipitation by ammonium sulfate} fractionation

The results of the experiments shown in Table 2 are presented in Figures 3 and 4, showing the concentration, purity and recovery of C-PC. In these Figures, the same letters mean the same results at $\mathrm{p}<0.05$.

In Figure 3, it can be seen that the purity was the same in all the trials studied. On the other hand, for C-PC concentration, the highest value $\left(2.2 \mathrm{mg} \mathrm{mL}^{-1}\right)$ was obtained in the trial using 0-20\%/20-50\% of $\left(\mathrm{NH}_{4}\right)_{2} \mathrm{SO}_{4}$ saturation, but this result was statistically equal to $0-25 \% / 25-50 \%$. Moreover, the fractionations 0-35\%/35-50\% and 0-40\%/40$50 \%$ were equal for all the responses evaluated.

The recovery of C-phyocycanin (Figure 4) was the same for trials 1 and 2 (Table 2), which was better than in trials 3 and 4 . Thus a trial was carried out using a fractionation of 0-20\%/20-50\%, obtaining a C-PC concentration of $2.2 \mathrm{mg} \mathrm{mL}^{-1}$, purity of 0.72 and recovery of $81.7 \%$.

\section{Purification by fractionation versus direct precipitation}

The results for extract purity and C-phycocyanin concentration when using a fractionation of 0-20\%/20-50\% saturation and direct precipitation at $50 \%$ are presented in Table 5. There was some variation in the level responses since the latter experiments were done with a batch of 


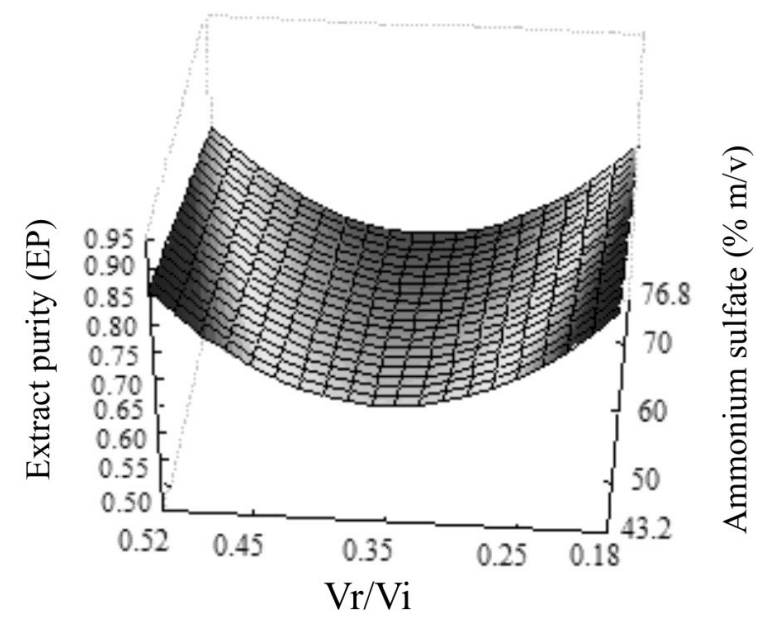

(A)

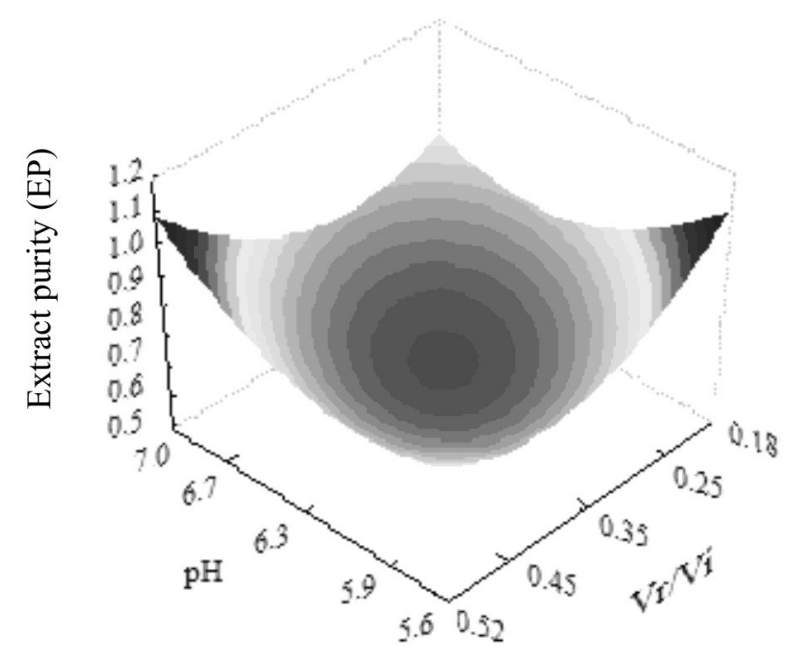

(C)

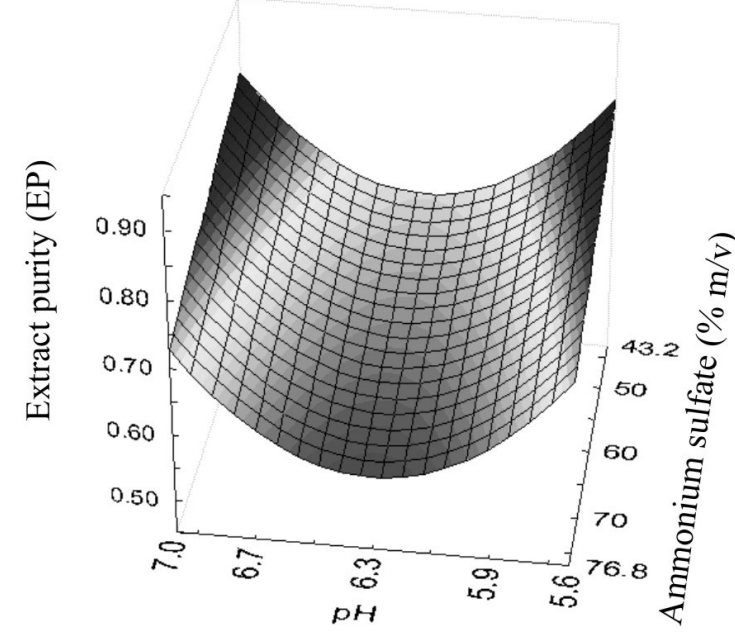

(E)

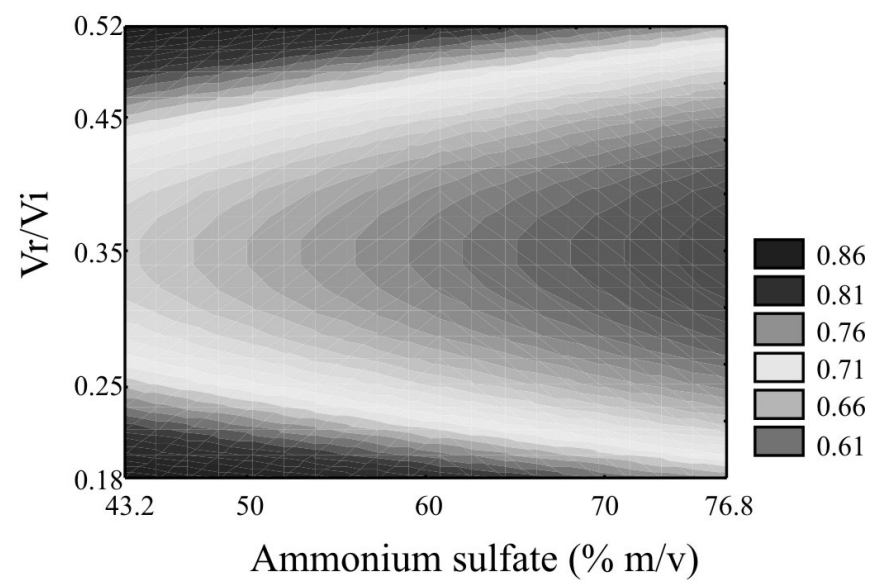

(B)

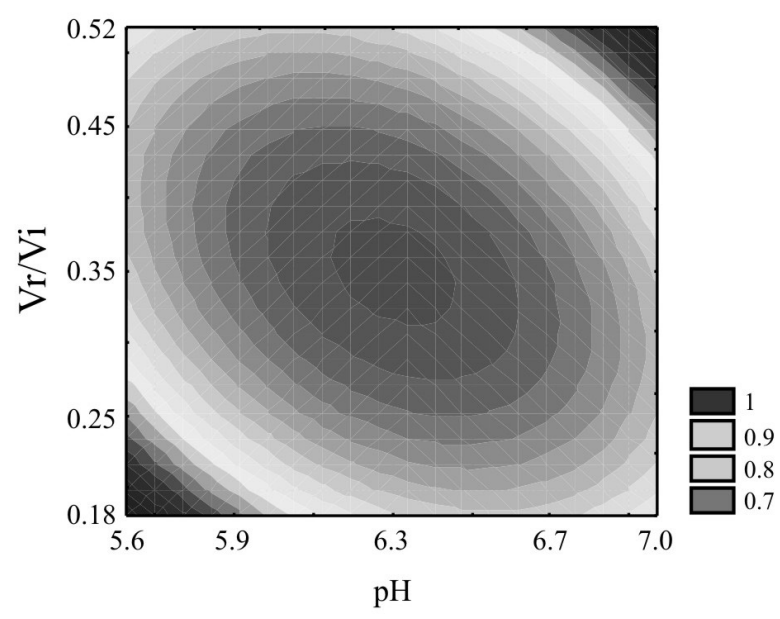

(D)

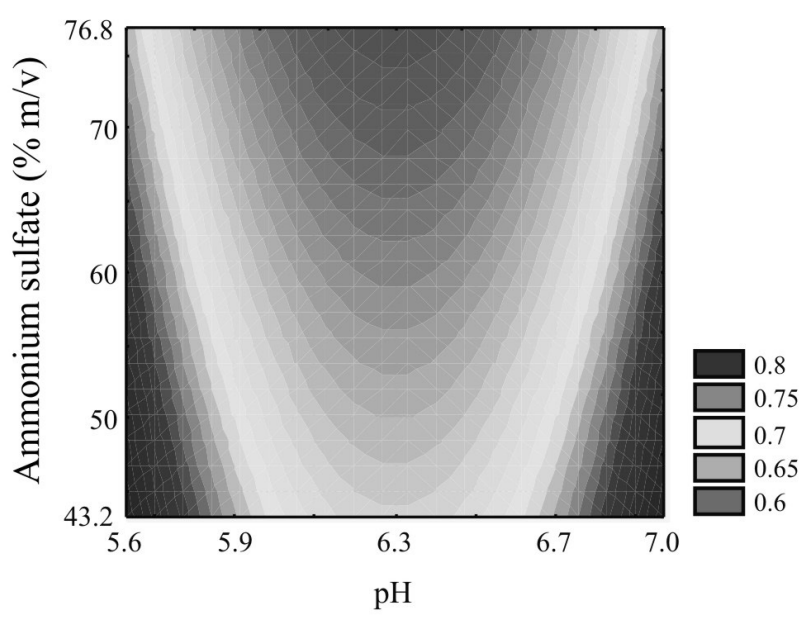

(F)

Figure 2. Response surfaces and contours diagrams for the extract purity as a function of ammonium sulfate concentration, $\mathrm{pH}$ and resuspension volume/ initial volume ratio. 


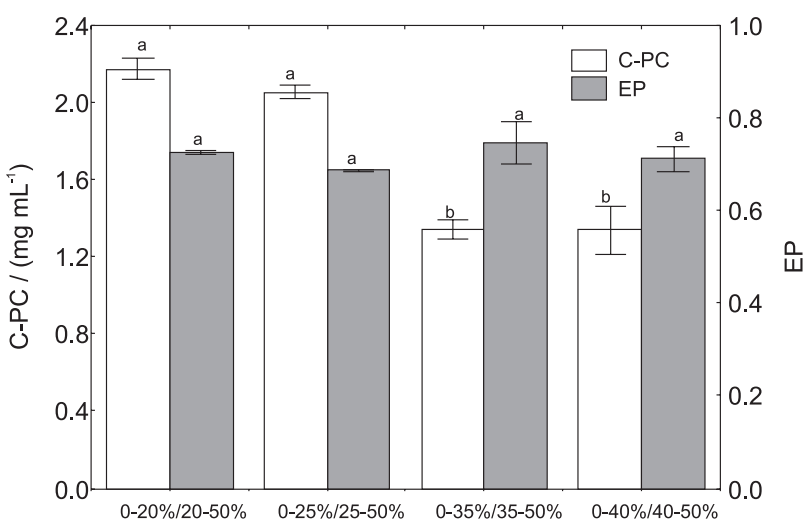

Figure 3. C-PC concentration $\left(\mathrm{mg} \mathrm{mL}^{-1}\right)$ and extract purity when ammonium sulfate fractionation was used.

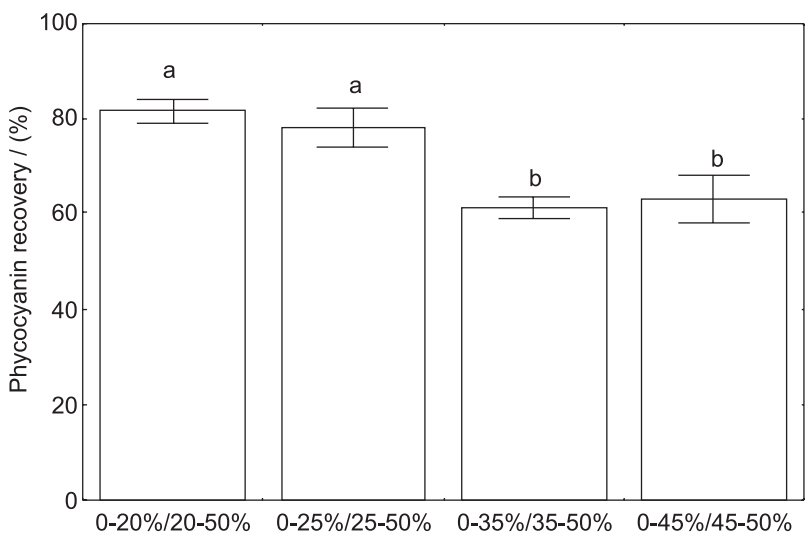

Figure 4. Recovery (\%) for C-PC when ammonium sulfate fractionation was used.

Table 5. Extract purity (EP), C-phycocyanin concentration (C-PC) and recovery (REC) obtained in the comparison between the experimental design conditions and ammonium sulfate fractionation

\begin{tabular}{lcc}
\hline Response/saturation & $50 \%$ & $0-20 \% / 20-50 \%$ \\
\hline EP & 0.72 & 0.88 \\
$\mathrm{C}-\mathrm{PC} /\left(\mathrm{mg} \mathrm{mL}^{-1}\right)$ & 1.69 & 1.66 \\
$\mathrm{REC} /(\%)$ & 91.7 & 83.8 \\
\hline
\end{tabular}

biomass. In order to compare the experiments, they were run again, with a new bath of biomass and carried out in triplicate.

The evaluation showed that only extract purity response was statistically different $(\mathrm{p}<0.05)$. The first step in the fractional precipitation started with $20 \%$ ammonium sulfate saturation; which mainly salted some other proteins with little improvement in the purity ratio. The C-PC fraction was then salted out with $50 \%$ ammonium sulfate concentration and dissolved in phosphate buffer $\left(0.05 \mathrm{~mol} \mathrm{~L}^{-1}, \mathrm{pH} 7.0\right)$, eliminating other basic proteins to a remarkable degree with a simultaneous purity improvement. Thus, purity results by fractionation were better than those obtained by direct precipitation at $50 \%$ saturation. This makes purification by fractionation more interesting for industry, because in a purification process, all responses studied are important, but the purity request is a key factor to be taken into account, since it is decisive for the purification step number definition. In this case, both treatments lead to a purity value higher than 0.7 , but fractionation allowed for a more robust process than direct precipitation at $50 \%$ saturation.

\section{Conclusions}

This study reported, for the first time, the purification optimization of C-phycocyanin from Spirulina platensis by precipitation using experimental design and response surfaces analysis. Effects of ammonium sulfate concentration, resuspension volume/initial volume ratio and $\mathrm{pH}$ of resuspension were studied in a complete factorial design. The best conditions determined were: low ammonium sulfate concentration, high $\mathrm{pH}$ (7.0) and resuspension volume/initial volume ratio of 0.52 .

The best results were: fractionation at $0-20 \% / 20-$ $50 \%$ saturation, resulting in a product with $1.66 \mathrm{mg} \mathrm{mL}^{-1}$ concentration, $83.8 \%$ recovery and 0.88 purity, with a purification factor of 1.7 times (70\% increase). Overall, results reported here demonstrated the importance of purification optimization steps, mainly when applied to food, since low cost and high recovery are necessary, and ammonium sulfate precipitation is an economically feasible alternative with no toxic reagents, allowing this precipitation technique in food use.

\section{Acknowledgments}

We wish to acknowledge the support of Conselho Nacional de Desenvolvimento Científico e Tecnológico (CNPq/MCT), of Coordenação de Aperfeiçoamento de Pessoal de Nível Superior (CAPES), and of Fundação de Amparo à Pesquisa do Estado do Rio Grande do Sul (FAPERGS) to this work.

\section{References}

1. Román, B. R.; Pez, J. M. A.; Fernandéz, F. C. A.; Grima, M. E.; J. Biotechnol. 2002, 93, 73.

2. Viskari, J. P.; Colyer, C. L.; J. Chromatogr., A 2002, 972, 269.

3. Kronick, M. N.; J. Immunol. Methods 1986, 92, 1.

4. Bennett, A.; Bogorad, L.; J. Cell Biol. 1973, 58, 419. 
5. Vonshak, A.; Spirulina Platensis (Arthospira)-Physiology, Cell Biology and Biotechnology, Taylor \& Francis: London, 2002.

6. Romay, Ch.; González, R.; Lendon, N.; Remirez, D.; Rimbau, V.; Curr. Protein Pept. Sci. 2003, 4, 207.

7. Reddy, C. M.; Subhashini, J.; Mahipal, S. V. K.; Bhat, V. B.; Reddy, S. P.; Kiranmai, G.; Madyastha, K. M.; Reddanna, P.; Biochem. Biophys. Res. Commun. 2003, 304, 385.

8. Bhat, V. B.; Madyasatha, K. M.; Biochem. Biophys. Res. Commun. 2001, 285, 262.

9. Estrada, J. E. P.; Bescós, P. B.; Fresno, A. M. V.; Il Farmaco 2001, 56, 497.

10. Bhat, V. B.; Madyasatha, K. M.; Biochem. Biophys. Res. Commun. 2000, 275, 20.

11. Reis, A., Mendes, A.; Lobo-Fernandes, H.; Empis, J. A.; Novais, J. M.; Bioresour. Technol. 1998, 66, 181.

12. Costa, J. A. V.; Colla, L. M.; Filho, P. F. D.; Bioresour. Technol. 2004, 92, 237.

13. Patil, G.; Chethana, S.; Sridevi, A. S; Raghavarao, K. S. M. S.; J. Chromatogr., A 2006, 1127, 76.

14. Palomares, M.; Nunes, L.; Amador, D.; J. Chem. Technol. Biotechnol. 2001, 76, 1273.

15. Wheelwright, S. M.; Biotechnol. 1987, 5, 189.

16. Araujo, J. M. A.; Química de Alimentos, Imprensa Universitária Universidade Federal de Viçosa: Viçosa, 1995.

17. Pessoa, A. Jr.; Kilikian, B. V.; Purificação de Produtos Biotecnológicos, Manole: Barueri, 2005.

18. Bermejo, R.; Talavera, E. M.; Alvarez-Pez, J. M.; Orte, J. C.; J. Chromatogr., A 1997, 778, 441.

19. Liu, L.; Chen, X.; Zhang, X.; Zhang, Y. Z.; Zhou, B. C.; J. Biotechnol. 2005, 116, 91 .

20. Soni, B.; Kalavadia, B.; Trivedi, U.; Madamwar, D.; Process Biochem. 2006, 41, 2017.

21. Stamford, T. L. M.; Stamford, N. P.; Coelho, L. C. B. B.; Araújo, J. M.; Bioresour. Technol. 2002, 83, 105.

22. Ninawe, S.; Kapoor, M.; Kuhad, R. C.; Bioresour. Technol. 2008, 99, 1252.

23. Amersham Pharmacia Biotech; Protein Purification Handbook, $3^{\text {rd }}$ ed., Uppsala Catalog.
24. Ferreira, L. C.; Santos, W. N. L.; Quintella, C. M.; Neto, B. B.; Bosque-Sendra, J. M.; Talanta 2004, 63, 1061.

25. Ferreira, S. L. C.; Bruns, R. E.; Ferreira, H. S.; Matos, G. D.; David, J. M.; Brandão, G. C.; Silva, E. G. P.; Portugal, L. A.; Reis, P. S.; Souza, A. S.; Santos, W. N. L.; Anal. Chim. Acta 2007, 597, 179.

26. Costa, J. A. V.; Linde, G. A.; Atala, D. I. P; Mibielli, G. M.; Krüger, R. T.; World J. Microbiol. Biotechnol. 2000, 16, 15.

27. Zarrouk, C.; PhD Thesis, University of Paris, France, 1996.

28. Silveira, S. T.; Burkert, J. F. M.; Costa, J. A. V.; Burkert, C. A. V.; Kalil, S. J.; Bioresour. Technol. 2007, 98, 1629.

29. Box, G. E.; Hunter, J. S.; Statistics for Experimenters: an Introduction to Design, Data Analysis and Model Building, Jonh Wiley \& Sons: New York, 1978.

30. Abalde, J.; Betancourt, L.; Torres, E.; Cid, A.; Barwell, C.; Plant Sci. 1998, 136, 109.

31. Rodrigues, M. I.; Iemma, A. F.; Planejamento de Experimentos e Otimização de Processos-Uma Estratégia Sequencial de Planejamentos, Casa do Pão: Campinas, 2005.

32. Kalil, S. J.; Suzan, R.; Maugeri, F.; Rodrigues, M. I.; Appl. Biochem. Biotechnol. 2001, 94, 257.

33. Sarada, R.; Pillai, M. G.; Ravishankar, G. A.; Process Biochem. 1999, 34, 95.

34. Fukui, K.; Saito, T.; Noguchi, Y.; Kodera, Y.; Matsushima, A.; Nishimura, H.; Inada, Y.; Dyes Pigments 2004, 63, 89.

35. Antelo, F. S.; Costa, J. A. V.; Kalil, S. J.; Biochem. Eng. J. 2008, $41,43$.

36. Bhaskar, S. U.; Gopalaswamy, G.; Raghu, R.; Indian J. Exp. Biol. 2005, 43, 277.

37. Boussiba, S.; Richmond, A. E.; Arch. Microbiol. 1979, 120, 155.

38. Cyanotech: http://www.cyanotech.com/, acessed in April, 2008.

Received: March 10, 2008

Web Release Date: October 15, 2008 